\title{
STRATEGI ANALISIS RANTAI PASOK (Supply chain) IKAN TENGGIRI (Studi Kasus di Bangliao Hasan Kecamatan Bangko Kabupaten Rokan Hilir Provinsi Riau)
}

\author{
Hazmi Arief ${ }^{(1}$ dan Ulfa Rizki Pradini ${ }^{(2}$ \\ 1) Dosen Fakultas Perikanan dan Kelautan Universitas Riau \\ 2) Mahasiswa Magister Agribisnis Fakultas Pertanian Universitas Riau \\ E-mail: hazmi_arief@yahoo.com
}

\begin{abstract}
ABSTRAK
Penelitian ini telah dilaksanakan pada bulan Februari 2017 di Bangliao Hasan Kelurahan Bagan Barat Kecamatan Bangko Kabupaten Rokan Hilir. Penelitian ini bertujuan untuk menganalisis kinerja rantai pasokan ikan Tenggiri dalam strategi penerapan Balanced Score Card (BSC) pada Bangliao Hasan. Adapun manfaat penelitian ini adalah diharapkan mampu menghasilkan alternative sebagai strategi rantai pasok yang dapat direkomendasikan kepada pihak perusahaan ikan segar untuk bisa dipertimbangkan dalam upaya peningkatan kinerja dan daya saing usahanya. Sistem pengukuran kinerja perusahaan dengan menggunakan kriteria tertentu yang merupakan penjabaran dari apa yang menjadi misi dan strategi perusahaan jangka panjang. Kriteria tersebut digolongkan menjadi empat perspektif yaitu: (1) perspektif keuangan, (2) perspektif pelanggan, (3) perspektif proses bisnis internal dan (4) perspektif pembelajaran dan pertumbuhan. Dengan menggunakan metode Balance Score Card maka Bangliao Hasan mampu mempertahankan usahanya atas dasar kegiatan sosial dan ekonominya. Hal yang harus diperhatikan oleh Banglio Hasan untuk memperbaiki kinerja perusahaan yang bertujuan meningkatkan rasio aktivitas, rasio peningkatan penjualan, rasio profitabilitas serta meningkatkan produktivitas karyawan guna keberlanjutan usaha.
\end{abstract}

Kata Kunci : Rantai Pasok, Balance Score Card

\section{ABSTRACT}

This research was conducted in February 2017 in Bangliao Hasan, West Bagan Village, Bangko District, Rokan Hilir Regency. This study aims to analyze the performance of the mackerel fish supply chain in the strategy of implementing the Balanced Score Card (BSC) in Bangliao Hasan. The benefits of this research are expected to be able to produce alternatives as supply chain strategies that can be recommended to fresh fish companies to be considered in an effort to improve performance and business competitiveness. System measurement of company performance by using certain criteria which is a translation of what the mission and long-term corporate strategy. These criteria are classified into four perspectives: (1) financial perspective, (2) customer perspective, (3) per internal business process perspective and (4) learning and growth perspective. By using the Balance Score Card 
method, Bangliao Hasan was able to maintain his business on the basis of his social and economic activities. Things that should be considered by Banglio Hasan to improve company performance which aims to increase the ratio of the activity, the ratio of sales increase, profitability ratios and increase employee productivity for business sustainability.

Keywords: Strategy, Supply Chain, Balance Score Card

\section{PENDAHULUAN}

Supply chain menyangkut tentang hubungan yang terus menerus mengenai barang, uang dan informasi. Barang umumnya mengalir dari hulu ke hilir, uang mengalir dari hilir ke hulu, sedangkan informasi mengalir baik dari hulu ke hilir maupun hilir ke hulu (dua arah).

Kecamatan Bangko merupakan salah satu kecamatan yang terdapat di Kabupaten Rokan Hilir. Kecamatan Bangko terdiri dari 10 Kepenghuluan dan 5 Kelurahan. Keseluruhan Kecamatan di Kabupaten Rokan Hilir mempunyai potensi dalam bidang perikanan. Salah satu sentra produksi perikanan yang terdapat di Kecamatan Bangko adalah di Kelurahan Bagan Barat. Sebagian besar kegiatan yang dilakukan masyarakat Kecamatan Bangko adalah usaha dalam bidang penangkapan, pengolahan dan pemasaran ikan.

$$
\text { Adapun jumlah produksi }
$$
perikanan tangkap menurut jenis ikan hasil penangkapan di Kecamatan Bangko pada tahun 2015 adalah ikan rucah 2.919,8 ton, ikan Cencaru 1.768,6 ton, ikan Senangin 1.563 ton, ikan Gulama 800 ton, ikan Tenggiri 536 ton, ikan Duri 442 ton, ikan Pari 367 ton, ikan Malung 359 ton, ikan Bawal 280,7 ton, ikan Selar 106,2 ton, udang 57 ton, ikan Belanak 9 ton, dan lain-lain (Badan Pusat Statistik Kabupaten Rokan Hilir, 2018).
Di Kelurahan Bagan Barat terdapat sebuah Bangliao Hasan. Bangliao adalah gudang atau tempat pendaratan ikan bagi nelayan baru pulang melaut. Bangliao Hasan sudah berdiri lebih kurang 92 tahun. Bangliao Hasan menampung berbagai jenis ikan hasil tangkapan nelayan, di antaranya ikan Tenggiri, ikan Senangin, ikan Bawal Putih, ikan Senohong, ikan Pari, ikan Sembilang, ikan Malong, ikan Cencaru. Bangliau distributor ikan segar sangat tergantung pada hasil tangkapan nelayan, sementara hasil tangkapan nelayan sendiri sangat tergantung pada kondisi serta iklim dan cuaca.

Rata-rata hasil tangkapan nelayan yang mendaratkan ikan di bangliao Hasan per harinya yaitu berkisar 500$1.200 \mathrm{Kg}$ pada saat musim ikan. Sedangkan pada saat tidak musim ikan per harinya yaitu berkisar 500-700 Kg. Selama ini Bangliao dinilai belum menerapkan strategi kinerja rantai pasok yang efisien, serta kurang mampu bersaing dengan Bangliao di luar daerah Bagan dalam pemasaran ikan hasil tangkapan. Hal ini dikarenakan jumlah ikan yang ditampung dari nelayan untuk penjualan komoditas mengalami penurunan, dalam sehari hanya menampung $500 \mathrm{~kg}$ dari yang biasanya menampung 1-2 ton per hari.

Penelitian ini bertujuan untuk menganalisis kinerja rantai pasokan ikan Tenggiri dalam strategi penerapan Balanced scorecard (BSC) pada Bangliao Hasan. Adapun manfaat penelitian ini adalah diharapkan mampu 
menghasilkan alternative sebagai strategi supply chain yang dapat direkomendasikan kepada pihak perusahaan ikan segar untuk bisa dipertimbangkan dalam upaya peningkatan kinerja dan daya saing usahanya.

\section{METODOLOGI PENELITIAN}

\section{a. Waktu dan Tempat Penelitian}

Penelitian ini telah dilaksanakan pada bulan Februari 2017 di Bangliao Hasan Kelurahan Bagan Barat Kecamatan Bangko Kabupaten Rokan Hilir. Penentuan lokasi dilakukan secara sengaja (purposive) dengan pertimbangan bahwa daerah ini merupakan salah satu daerah yang memiliki potensi perikanan yang cukup besar dan adanya masalah dalam efesiensi kinerja rantai pasok ikan di Kecamatan Bangko Kabupaten Rokan Hilir Provinsi Riau.

Dalam penelitian ini digunakan metode survey, yaitu penelitian yang mengambil sampel dari suatu populasi dengan menggunakan kuisioner sebagai alat pengumpul data pokok atau informasi langsung ke lapangan dengan cara pengamatan langsung dan wawancara dengan responden yang berpedoman pada daftar pertanyaan atau kuisioner.

\section{b. Metode Pengambilan Sampel}

Responden ditentukan dengan menggunakan teknik non probability sampling lalu menggunakan teknik snowball sampling yaitu suatu pendekatan untuk menemukan informan -informan kunci yang memiliki banyak informasi yang saling berkaitan. Adapun responden pada penelitian ini adalah Bangliao Hasan, Nelayan, Agen, Pedagang Pengecer dan Along-Along.

\section{c. Metode Analisis Data}

Untuk menganalisis strategi tingkat kinerja rantai pasokan ikan segar di Bangliau Hasan maka dianalisis dengan menggunakan metode Balanced scorecard (BSC) dengan mengukur tingkat efisiensi rantai pasokan. Metode Balanced scorecard (BSC) merupakan salah satu metode pengukuran kinerja perusahaan secara keseluruhan yang menjabarkan visi dan strategi perusahaan ke dalam 4 prespektif, yaitu prespektif keuangan, prespektif pelanggan, prespektif proses bisnis internal, dan prespektif pembelajaran dan pertumbuhan.

\section{1) Perspektif Keuangan}

Pengukuran kinerja Finansial dilaksanakan karena mempunyai peran penting dalam memacu pertumbuhan perusahaan secara cepat. Berbagai inovasi finansial meliputi (Kaplan dan Norton, 2000):

a) Total nilai keuntungan

$$
\text { Profitabilitas }=\frac{\text { Laba }}{\text { Penjualan }} \times 100 \%
$$

(Sartono, 1999)

b) Rasio aktivitas

Total aset turn over

(Harahap, 2006)

$$
=\frac{\text { penjualan }}{\text { total aset }} \times 100 \%
$$

c) Peningkatan penjualan

$$
\text { P. penjualan }=\frac{\text { P.tahun ini }- \text { P. tahun lalu }}{\text { P.tahun lalu }}
$$

(Harahap, 2006)

\section{2) Perspektif Pelanggan}

1. Retensi pelanggan (customer retention), mengukur tingkat dimana perusahaan dapat mempertahankan hubungan dengan pelanggan.

2. Akuisisi pelanggan (customer acquisition), mengukur tingkat 
keberhasilan unit bisnis menarik atau memenangkan pelanggan atau bisnis baru.

3. Kepuasan pelanggan (customer satisfaction), menilai tingkat kepuasan pelanggan terhadap kriteria kinerja tertentu, seperti tingkat pelayanan. Kepuasan pelanggan dapat diranking dengan skala 1-5, yaitu :

4. Profitabilitas pelanggan (customer profitability), mengukur laba bersih yang diperoleh perusahaan dari suatu target atau segmen pasar yang dilayani.

\section{3) Perspektif Proses Bisnis Internal}

1. Utilisasi Kapasitas

Utilisasi kapasitas merupakan indikasi dari naik turunnya biaya rantai pasok

2. Efisiensi Operasi

Efisiensi perusahaan berpengaruh pada tingkat produktivitasnya, kualitas, kepuasan konsumen, waktu dan biaya rantai pasok keseluruhan.

\section{4) Perspektif Pembelajaran dan Pertumbuhan}

Rasio ini menunjukkan tingkat produktivitas dari unit atau kegiatan yang dinilai dari kepuasan kerja, kesempatan pengembangan karir dan komitmen karyawan.

a) Tingkat Produktivitas Karyawan

$$
\text { Prod. Karyawan }=\frac{\text { Jlh. penjualan bersih }}{\text { Jumlah karyawan }}
$$

\section{III.HASIL DAN PEMBAHASAN}

Kondisi wilayah kepenghuluan Bagan Barat merupakan lokasi penelitian yang secara geografis dibatasi oleh daerah-daerah, yaitu :

a. Sebelah Utara berbatasan dengan Kepenghuluan Bagan Jawa. b. Sebelah Selatan berbatasan dengan Kelurahan Bagan Hulu.

c. Sebelah Barat berbatasan dengan Sungai Barkey.

d. Sebelah Timur berbatasan dengan Kelurahan Bagan Kota.

\section{Aset Bangliao Hasan}

Aset adalah semua hak yang dapat digunakan dalam operasi perusahaan. Adapun beberapa aset yang dimiliki oleh Banglia untuk membantu kinerja perusahaan yang memberikan manfaat ekonomi.

Tabel 1. Total Aset Bangliao Hasan

\begin{tabular}{|c|c|c|c|}
\hline No & Nama Aset & Unit & Harga (Rp) \\
\hline 1 & Tanah & - & 150.000 .000 \\
\hline 2 & Gedung & 1 & 120.500 .000 \\
\hline 3 & Listrik & - & 8.000 .000 \\
\hline 4 & Coolbox & 40 & 40.500 .0000 \\
\hline 5 & Lemari es & 8 & 8.000 .0000 \\
\hline 6 & Gerobak & 7 & 6.500 .000 \\
\hline \multirow[t]{2}{*}{7} & Timbangan & 8 & 8.000 .000 \\
\hline & Total & 64 & 341.500 .0000 \\
\hline
\end{tabular}

Berdasarkan Tabel 1 dapat dilihat bahwa nilai asset tertinggi Bangliao adalah tanah senilai Rp. 150.000.000 dan aset terendah Bangliao adalah Gerobak senilai Rp. 6.500.000. Jadi total aset yang dimiliki Bangliao adalah senilai Rp. 341.500.000.

\section{Volume Produksi Ikan Tenggiri di Bangliao Hasan}

Informasi yang berhubungan dengan volume produksi jauh lebih sulit diperoleh dari pada informasi yang terkait dengan pelaku usaha dan ketersediaan lapangan kerja.informasi volume produk sangat bermanfaat dalam memperkirakan permintaan pasar, harga, potensi produk yang masih dapat digali dan nilai produk yang seharusnya dapat dimaksimalkan. 
Berikut volume produksi ikan Grafik 1. Tenggiri di Bangliao Hasan seperti pada

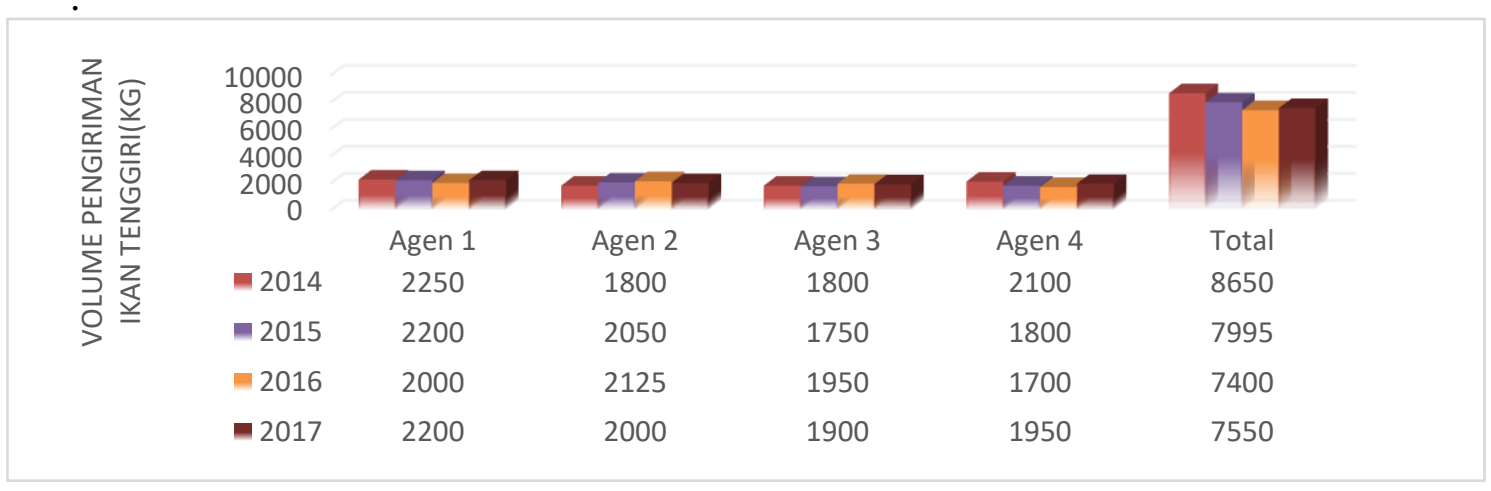

Grafik 1. Volume Produksi Ikan Tenggiri Di Bangliao Hasan

Berdasarkan Grafik 1 menunjukkan bahwa volume produksi pengiriman ikan Tenggiri mengalami kenaikan pada tahun 2017 dan mengalami penurunan paling rendah pada tahun 2016.

\section{PELAKU RANTAI PASOK Nelayan (Supplier)}

Nelayan yang dimaksud dalam penelitian ini adalah nelayan yang dalam usahanya tidak memiliki kapal sendiri, dalam melaut mereka menggunakan kapal milik orang lain atau sering disebut juragan, adapun penghasilan antara para nelayan dengan

Tabel 2. Karakteristik Nelayan Tangkap Bangliao Hasan

\begin{tabular}{cll}
\hline No & \multicolumn{1}{c}{ Uraian } & \multicolumn{1}{c}{ Keterangan } \\
\hline 1 & Alamat Responden & Kel. Bagan Barat Kec. Bangko Rokan \\
& & Hilir \\
2 & Jenis Ikan Hasil Tangkapan & Tenggiri, Senangin, Cencaru, Pari dan \\
& & Sembilang \\
3 & Biaya Produksi & Rp. 5.609.000 (sekali melaut) \\
4 & Pendapatan Bersih & Rp. 2.500.000 (sekali melaut) \\
5 & Sumber Modal (\%) & \\
& a) Seorang & - \\
& b)Lembaga Keuangan lain & $100 \%$ \\
6 & Bentuk Penjualan Hasil Tangkap & Ikan Segar \\
7 & Satuan Penjualan & Kilogram (Kg) \\
\hline
\end{tabular}

pemilik kapal tidak dengan sistem sewa kapal melainkan dengan sistem bagi hasil dari tangkapan para nelayan dengan kesepakatan yang telah ditentukan.

Nelayan menggunakan perahu berukuran sedang yang biasanya berkapasitas 3 sampai 4 orang (ABK) dan alat tangkap yang digunakan oleh nelayan ini adalah jenis alat tangkap jaring dan rata-rata dari mereka dalam sekali melaut membutuhkan waktu hanya satu hari saja karena memang kapasitas kapal yang berukuran sedang. Kilogram $(\mathrm{Kg})$ 
Berdasarkan Tabel 2 dapat dilihat bahwa Nelayan dengan biaya produksinya Rp. 5.609.000 dalam sekali melaut yang terdiri dari solar, oli, gas, lampu tixto, es, pancing, rokok dan makan nelayan.

Banyak nelayan ikan yang mendaratkan ikan di Bangliao Hasan Kelurahan Bagan Barat yang menghadapi permasalahan dalam kemampuan permodalan. Hal ini dapat dibuktikan bahwa 100 persen nelayan responden menggunakan pinjaman kredit non bank dimana biaya operasional yang dikeluarkan oleh nelayan menggunakan pinjaman dari tauke. Hal ini dikarenakan para nelayan lebih menyukai cara yang praktis untuk mendapatkan pinjaman sebagai kegiatan melaut serta untuk kehidupan sehari-hari tanpa memikirkan bunga yang lebih besar jika meminjam kepada tauke.

Nelayan cenderung tidak melakukan pinjaman kepada Bank karena proses pencairan dana yang sulit dan membutuhkan waktu yang lama, selain itu Bank juga memerlukan jaminan jika hendak memberikan pinjaman kepada nasabah. Lapangan pekerjaan yang terbatas di luar cuaca yang tidak kondusif untuk melaut, dan pemborosan menyebabkan banyak nelayan tidak dapat mengatur pola hidup mereka sementara mereka harus memenuhi kebutuhan hidup yang semakin tinggi.

\section{Bangliao Hasan}

Nelayan yang mendaratkan ikan di Bangliao Hasan ada 10 perahu. Bangliao Hasan memiliki 8 orang karyawan yang bekerja mulai dari pukul 08.00-17.00. Bangliao Hasan juga memiliki 8 orang agen. Agen mengambil ikan dari Pak Hasan tanpa menggunakan modal, ikan yang diambil dari bangliao langsung dijual ke pelanggan masing-masing, setelah ikan terjual barulah agen membayar ikan yang diambilnya dari Bangliao Hasan.

Rata-rata hasil tangkapan nelayan yang mendaratkan ikan di Bangliao Hasan per harinya yaitu berkisar 500$1.200 \mathrm{Kg}$ pada saat musim ikan. Sedangkan pada saat tidak musim ikan per harinya yaitu berkisar 500-700 Kg. Alat tangkap yang digunakan nelayan adalah jaring dengan ukuran kapal $<5$ GT.

Jenis ikan yang didaratkan di bangliao Hasan yaitu ikan Tenggiri, ikan Senangin, ikan Bawal Putih, ikan Senohong, ikan Pari, ikan Sembilang, ikan Malong, ikan Cencaru. Harga dari masing-masing ikan sudah ditetapkan oleh tauke itu sendiri.

Harga masing-masing ikan hasil tangkapan berdasarkan jenis ikan di Bangliao Hasan, sebagai berikut :

Tabel 3. Jenis dan Harga Ikan Pasaran dari Bangliao Hasan

\begin{tabular}{clc}
\hline No & \multicolumn{1}{c}{ Jenis Ikan } & Harga $(\mathbf{R p} / \mathbf{K g})$ \\
\hline 1 & Ikan Senangin & 40.000 \\
2 & Ikan Tenggiri & 45.000 \\
3 & Ikan Malong & 22.000 \\
4 & Ikan Sembilang & 20.000 \\
5 & Ikan Pari & 30.000 \\
6 & Ikan Cencaru & 12.000 \\
7 & Ikan Bawal Putih & 40.000 \\
8 & Ikan Senohong/Kurau & 40.000 \\
\hline
\end{tabular}


Dari Tabel 3 diatas dapat diketahui bahwa ikan Tenggiri memiliki harga yang paling tinggi di antara ikan lainnya diikuti dengan ikan Senangin, Bawal Putih, Senohong/Kurau, Pari, Malong, Sembilang dan ikan yang memiliki ikan harga rendah adalah ikan Cencaru.

Di Bangliao Hasan harga ikan ditentukan oleh tauke sesuai dengan kualitas ikan serta jumlah dan ukuran

Tabel 4. Harga Beli dan Harga Jual Ikan Tenggiri pada Lembaga Pemasaran Berdasarkan Tipenya.

\begin{tabular}{lcccccccc}
$\begin{array}{c}\text { Lembaga } \\
\text { Pemasaran }\end{array}$ & \multicolumn{3}{c}{ Harga Beli Ikan (Rp/Kg) } & \multicolumn{5}{c}{ Harga Jual Ikan (Rp/Kg) } \\
& $\mathbf{A}$ & $\mathbf{B}$ & $\mathbf{C}$ & $\mathbf{D}$ & $\mathbf{A}$ & $\mathbf{B}$ & $\mathbf{C}$ & D \\
\hline Nelayan & - & - & - & - & 36.000 & 30.000 & 24.000 & 18.000 \\
Bangliao & 36.000 & 30.000 & 24.000 & 18.000 & 41.000 & 35.000 & 29.000 & 21.000 \\
Agen & 40.000 & 35.000 & 29.000 & 21.000 & 42.000 & 37.000 & 31.000 & 23.000 \\
P. Pengecer & 42.000 & 37.000 & 31.000 & 23.000 & 45.000 & 39.000 & 33.000 & 25.000 \\
Along-along & 45.000 & 39.000 & 27.000 & 20.000 & 50.000 & 42.000 & 30.000 & 25.000 \\
\hline
\end{tabular}

Sumber : Data Primer

Keterangan :

A : Grade A

B : Grade B

$\mathrm{C}$ : Grade C

$\mathrm{D}:$ Grade D

Pada Tabel 3 dapat diketahui bahwa Perbedaan harga jual pada tingkat nelayan dengan agen, pedagang pengecer dan along-along disebabkan karena harga jual produsen sudah ditetapkan berdasarkan kesepakatan. Penentuan harga jual ini tentunya harus dapat menutupi biaya pemasaran atau operasional dan pedagang dapat memperoleh laba. Berdasarkan pendapat Buchari (2007), bahwa suatu perusahaan harus menetapkan harga sesuai dengan nilai yang diberikan dan dipahami pelanggan.

\section{Agen (Distributor)}

Agen dalam penelitian ini adalah lembaga pemasaran perikanan yang ikan. Bangliao menjalankan usahanya dengan menggunakan modal sendiri tanpa tidak melibatkan lembaga keuangan lain. Agen juga akan membeli ikan dari Bangliao Hasan untuk menjualnya kembali. Agen disini sudah sebagai agen menetap yang menjual hasil pembeliannya dengan taksiran harga jual sesuai harga jual di pasar. 
Jenis pembelian yang dibeli oleh agen mayoritas adalah ikan yang masih segar, kemudian agen menjual kembali tanpa merubah kondisi ikan tersebut, maksudnya ikan tersebut masih dalam keadaan segar. Dalam hal ini agen hanya melakukan penaksiran harga jual yang berlaku sesuai harga pasar kemudian melakukan pengemasan ikan dan menjual kembali dalam bentuk yang sama tanpa memberikan perlakuan khusus. Rata-rata dalam sekali transaksi mereka mampu mengambil ikan dari tauke sebanyak 150-200 kg per hari.

Kegiatan yang dilakukan oleh agen yaitu kaitannya dengan fungsi pemasaran adalah penaksiran harga, mensortir jenis ikan, tawar menawar dan pengemasan ikan ke dalam bak fiber. Penaksiran harga dalam hal ini adalah para agen mampu menaksir berbagai jenis harga ikan yang diberikan oleh tauke. Kegiatan mensortir jenis ikan dalam hal ini adalah memilah berbagai jenis ikan yang akan diambilnya. Kegiatan pengemasan yang dilakukan oleh para agen bertujuan untuk mengemas ikanikan yang selanjutnya akan didistribusikan kepada pembeli berikutnya, kegiatan pengemasan ini juga bertujuan untuk menjaga kualitas ikan agar tetap segar karena proses pengemasan ini juga termasuk dalam proses pengewatan ikan.

\section{Pedagang Pengecer (Retailer)}

Pedagang pengecer dalam penelitian ini adalah pedagang pengecer dari Rokan Hilir membeli ikan dari agen. Pedagang pengecer yang menjual ikan di daerah Rokan Hilir ini terdapat di Pasar Bagan. Jenis ikan yang dipasarkan di pasar ini termasuk jenis ikan yang berasal dari Bangliao yaitu ikan Tenggiri, ikan Senangin, ikan Cencaru, ikan Sembilang, ikan Malong, ikan Pari dan ikan Gulama. Akan tetapi dalam penelitian ini hanya fokus dengan satu jenis ikan saja yaitu Ikan Tenggiri.

Pedagang pengecer hanya mampu membeli ikan sekitar 50-60 Kg karena terbatasnya modal yang dimiliki dan apabila pengecer melakukan pembelian lebih banyak dari yang biasanya akan beresiko ikan tidak habis terjual. Dari sekian banyaknya ikan yang dibeli pedagang pengecer, ikan Tenggiri adalah permintaan konsumen yang paling tinggi sehingga setiap pembelian pedagang pengecer akan membeli lebih banyak ikan Tenggiri rata-rata $20-30 \mathrm{Kg}$.

\section{Pedagang Along-along (Retailer)}

Responden dalam penelitian ini juga melibatkan pedagang along-along yang membeli ikan dari agen menetap bangliao dan menjualnya kembali di daerah Bagan dengan berkeliling menggunakan sepeda motor serta bakulnya. Pedagang along-along yang datang ke agen menetap bangliao Hasan berjumlah 5 orang.

Sistem dalam pemasaran ini adalah pedagang along-along datang kepada agen menggunakan sepeda motor dengan bak keranjang atau disebut juga dengan bakul untuk membeli ikan segar dengan modal sendiri tanpa ada pinjaman dari lembaga lain. Dalam pemasarannya kembali, along-along hanya mampu membeli ikan sekitar 20-50 Kg karena terbatasnya modal yang mereka miliki. Dari banyaknya ikan yang dibeli pedagang along-along dari agen, pedagang along-along lebih banyak membeli ikan Tenggiri dengan rata-rata 20-30 Kg setiap sekali pembelian. Fungsi dari pemasaran along-along ini adalah menyalurkan ikan kepada para konsumen atau pelanggan mereka. 


\section{Konsumen (Customer)}

Konsumen pada saluran rantai pasok dalam penelitian ini adalah masyarakat umum yang bertempat tinggal di Kelurahan Bagan Barat Kecamatan Bangko.

\section{Kinerja Rantai Pasok Ikan Tenggiri}

Konsep Balanced Scorecard dikembangkan untuk melengkapi pengukuran kinerja keuangan dan sebagai alat ukur yang cukup penting bagi organisasi perusahaan untuk merefleksikan pemikiran baru dalam era competitive dan efektivitas organisasi (Kaplan dan Norton, 1996).

Konsep ini memperkenalkan suatu sistem pengukuran kinerja perusahaan dengan menggunakan kriteria tertentu yang merupakan penjabaran dari apa yang menjadi misi dan strategi perusahaan jangka panjang. Kriteria tersebut digolongkan menjadi empat perspektif yaitu: (1) perspektif keuangan, (2) perspektif pelanggan, (3) perspektif proses bisnis internal dan (4) perspektif pembelajaran dan pertumbuhan.

\section{Perspektif Keuangan}

Tingkat profitabilitas menunjukkan kemampuan perusahaan dalam meraih laba dari usaha-usaha yang telah dilakukannya. Berdasarkan data yang diperoleh dari Bangliao Hasan maka peneliti dapat menghitung total nilai keuntungan tahun 2014 sampai dengan tahun 2017 seperti di bawah ini :

1. Rasio Profitabilitas

Profitabilitas suatu perusahaan menunjukkan perbandingan antara laba dengan aktiva atau modal yang menghasilkan laba tersebut, dengan kata lain profitabilitas adalah kemampuan perusahaan untuk menghasilkan laba selama periode tertentu.

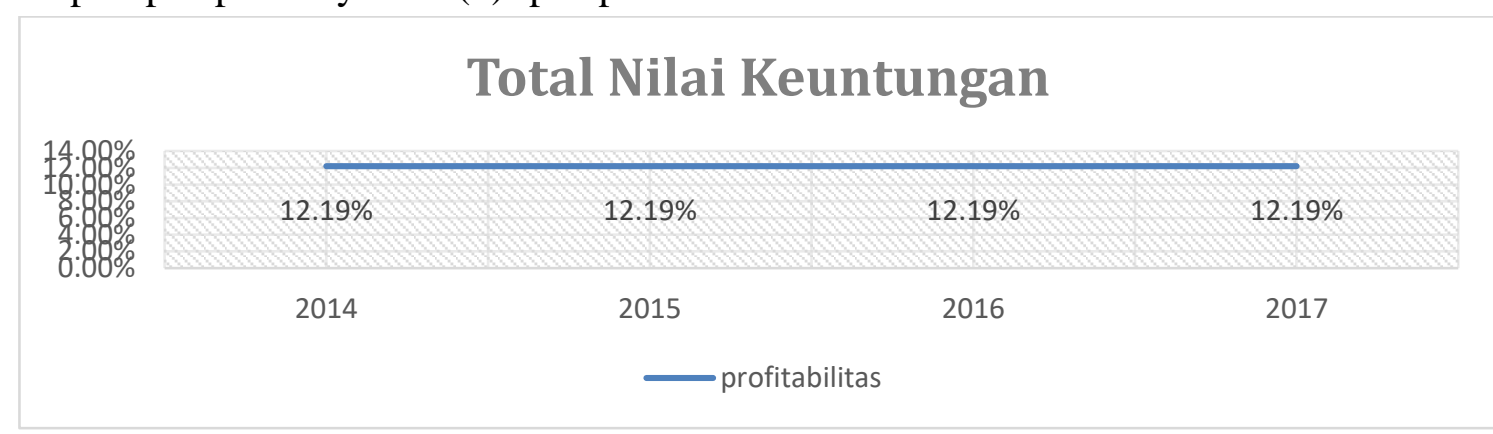

Grafik 2. Rasio Profitabilitas Rantai Pasok Ikan Tenggiri di Bangliao Hasan

Berdasarkan hasil uji Rasio Profitabilitas yang dilakukan pada Bangliao Hasan selama periode 2014 sampai periode 2017 memiliki trendline yang tetap atau tidak mengalami trendline yang menurun dan meningkat. Artinya, rasio tersebut menunjukkan bahwa Bangliao Hasan masih dapat mempertahankan profitabilitas walau laba dan penjualan setiap tahunnya menurun. Hal ini terjadi karena penjualan ikan Tenggiri selama periode 2014 sampai periode 2017 menurun sehingga laba perusahaan otomatis akan menurun juga.

\section{Rasio Aktivitas}

Rasio aktivitas adalah rasio yang digunakan untuk mengukur efektivitas perusahaan dalam menggunakan aktiva yang dimilikinya. Atau dapat dikatakan bahwa rasio digunakan untuk mengukur tingkat efisiensi pemanfaatan sumber daya perusahaan. Dalam penelitian ini yang menjadi aktivanya adalah total aset turn over (Kamsir, 2012). 


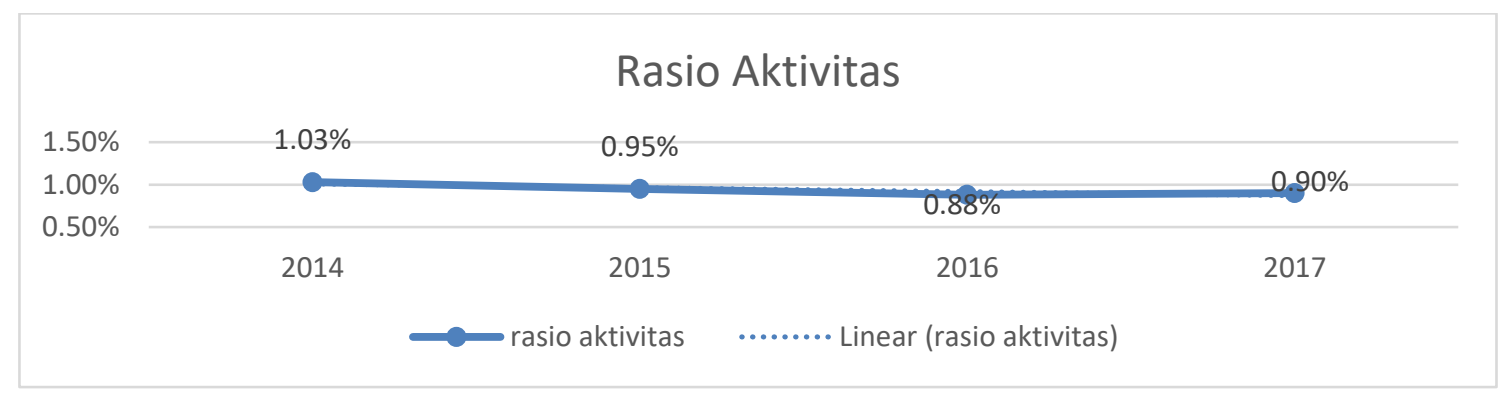

Grafik 3. Rasio Aktivitas Rantai Pasok Ikan Tenggiri di Bangliao Hasan

Berdasarkan hasil uji rasio aktivitas yang dilakukan selama periode 2014 sampai dengan 2016 pada Bangliao Hasan memiliki trendline yang menurun dan mulai meningkat sebesar $0,02 \%$ pada periode 2017 . Hal ini menunjukkan bahwa pada nilai rasio tersebut terlihat penggunaan aktiva oleh Bangliao Hasan dalam menghasilkan laba masih belum efesien. Kondisi ini tergambar dari aset yang dimiliki Bangliao lebih besar dibanding penjualan ikan Tenggiri yang setiap tahunnya menurun sehingga mengakibatkan Bangliao belum efektif dalam memanfaatkan aktiva yang dimilikinya.

\section{Pertumbuhan Penjualan}

Penjualan merupakan kriteria penting untuk menilai profitabilitas perusahaan dan merupakan indikator utama atas aktivitas perusahaan (Andriyani, 2013). Menurut Kennedy (2013), pertumbuhan penjualan adalah kenaikan jumlah penjualan dari tahun ke tahun atau dari waktu ke waktu.

Berdasarkan hasil penjualan ikan Tenggiri pada Bangliao selama periode 2014 sampai 2017, maka dapat diketahui peningkatan penjualan ikan

Tabel 5. Retensi Pelanggan (Customer retention) Rantai Pasok Ikan Tenggiri di Bangliao Hasan

\begin{tabular}{lcccc}
\hline Bangliao Hasan & $\mathbf{2 0 1 4}$ & $\mathbf{2 0 1 5}$ & $\mathbf{2 0 1 6}$ & $\mathbf{2 0 1 7}$ \\
\hline Jumlah Pelanggan Tetap & 126 & 146 & 152 & 164 \\
Total Pelanggan & 146 & 152 & 164 & 176 \\
Retensi Pelanggan (\%) & 90 & 92,1 & 92,6 & 93,1 \\
\hline
\end{tabular}

Tenggiri pada periode 2017 adalah sebagai berikut :

Pertumbuhan Penjualan $=(309.550 .000$

$-303.400 .000 / 303.400 .000 \times 100 \%$

$$
=0,02 \%
$$

Hasil uji peningkatan penjualan yang dilakukan pada Bangliao Hasan selama periode 2017 memiliki nilai pertumbuhan penjualan sebesar $0,02 \%$. Hal ini disebabkan meningkatnya penjualan pada periode 2016 (Rp.303.400.000) sampai periode 2017 (Rp.309.550.000).

\section{Perspektif Pelangganan \\ Retensi pelanggan retention)}

(Customer

Menurut Lewis M (2009) retensi pelanggan adalah perilaku pelanggan untuk mempertahankan sesuatu dari produsen ataupun produk yang dibuat oleh produsen seperti karena harganya yang murah ataupun terkenalnya suatu merk tertentu.

Berdasarkan data yang didapat dari Bangliao maka peneliti dapat memperoleh retensi pelanggan Bangliao seperti pada tabel berikut : 
Tabel 5 menunjukkan bahwa hasil uji retensi pelanggan yang dilakukan pada Bangliao selama periode 2014 sampai dengan 2017 meningkat. Artinya, uji retensi pelanggan tersebut menunjukkan bahwa Bangliao berhasil untuk mempertahankan hubungan dengan pelanggannya, terbukti dari kenaikan jumlah pelanggan dan jumlah pelanggan yang bertahan selama periode tersebut.

\section{Akuisisi Pelanggan (Customer Acquisition)}

Berdasarkan data yang didapat dari Bangliao maka peneliti dapat memperoleh akuisisi pelanggan Bangliao Hasan seperti pada tabel berikut :

Tabel 6. Akuisisi Pelanggan (Customer acquisition) Bangliao Hasan Pada Rantai Pasok Ikan Tenggiri

\begin{tabular}{lcccc}
\hline Akuisisi Pelanggan & 2014 & 2015 & 2016 & 2017 \\
\hline Jumlah Pelanggan Baru & 20 & 6 & 12 & 12 \\
Total Pelanggan & 146 & 152 & 164 & 176 \\
Retensi (\%) & 14 & 4 & 7,3 & 6,8 \\
\hline
\end{tabular}

Tabel 5 menunjukkan bahwa hasil uji akuisisi pelanggan yang dilakukan pada Bangliao selama periode 2014 sampai dengan 2017 menurun. Artinya, uji akuisisi pelanggan tersebut menunjukkan bahwa Bangliao berhasil menarik pelanggan baru terbesar pada periode 2014 saja dengan jumlah pelanggan 20 orang, sedangkan pada periode 2015 Bangliao menarik pelanggan hanya 6 orang saja, dan periode 2016 sampai dengan 2017 ditemukan pelanggan baru dengan jumlah yang sama yaitu 12 pelanggan dengan retensi yang menurun.

\section{Kepuasan Pelanggan (Customer Satisfaction)}

Dalam penelitian ini diketahui bahwa kinerja Bangliao Hasan dapat dikategorikan pada ranking 4 yaitu agak memuaskan. Pelanggan merasa puas dengan produk ikan Tenggiri karena diberikan pengalaman yang baik bagi para konsumen. Dilihat dari kualitas komoditinya, Bangliao memiliki produk yang sesuai standar pasar dan reputasi produk yang sesuai standar yang diminta dan dilihat dari kualitas layanan, Bangliao mempunyai hubungan yang baik dengan para pelanggan dan mampu mempertahankan pelanggan serta menarik pelanggan baru selama periode 2014 sampai dengan 2017.

\section{Profitabilitas Pelanggan (Customer Profitability)}

Berdasarkan analisis total keuntungan yang diuji dengan uji rasio profitabilitas maka dalam penelitian ini dihasilkan trendline rasio profitabilitas yang menetap selama periode 2014 sampai dengan 2017 dengan rasio $12,19 \%$. Rasio profitabilitas ini digunakan dalam mengukur efektivitas manajemen Bangliao secara keseluruhan sebagaimana ditunjukkan dari total nilai keuntungan yang diperoleh dari penjualan selama periode 2014 sampai 2017.

Berdasarkan hasil wawancara yang diperoleh dari Bangliao Hasan, rasio profitabilitas menetap dengan rasio $12,19 \%$ disebabkan oleh hasil produksi yang tidak menetap setiap tahunnya. 
Perspektif Proses Bisnis Internal

Berikut perspektif bisnis internal rantai pasok ikan Tenggiri di Bangliao Hasan :

Tabel 6. Perspektif Proses Bisnis Internal Rantai Pasok Bangliao Hasan

\begin{tabular}{|c|c|c|c|}
\hline No & Tujuan & Ukuran & Target \\
\hline 1 & $\begin{array}{l}\text { Utilisasi } \\
\text { Kapasitas }\end{array}$ & - Realisasi biaya rantai pasok & $\begin{array}{l}\text { - Meminimalisir } \\
\text { semaksimal mungkin }\end{array}$ \\
\hline 2 & Efisiensi Operasi & $\begin{array}{l}\text { - Efisiensi siklus rantai pasok } \\
\text { - Rata-rata waktu respon } \\
\text { - Efisiensi waktu penyediaan } \\
\text { barang } \\
\text { - Efisiensi tenaga kerja } \\
\text { - Jenis pengadaan ikan } \\
\text { Tenggiri }\end{array}$ & $\begin{array}{l}\text { - Menekan biaya rantai } \\
\text { pasok } \\
\text { - } 1 \text { hari kerja } \\
\text { - Maksimal } 7 \text { hari kerja } \\
\text { - Masing-masing pekerja } \\
\text { dapat menangani } \\
\text { seluruh pesanan. } \\
\text { - Terdapat } 4 \text { tipe ikan } \\
\text { Tenggiri }\end{array}$ \\
\hline
\end{tabular}

Tabel di atas menunjukkan bahwa perspektif proses bisnis internal dinyatakan baik ditinjau dari tujuan dalam utilisasi bahwa Bangliao Hasan memiliki ukuran merealisasi biaya rantai pasok dengan target meminimalisir semaksimal mungkin, tujuan efisiensi operasi juga memiliki ukuran efisiensi siklus rantai pasok dalam target menekan biaya rantai pasok, rata-rata waktu respon dengan 1 hari kerja, efisiensi waktu penyediaan barang dengan target maksimal 7 hari kerja, efisiensi tenaga kerja dengan target masing-masing pekerja di Bangliao ini dapat menangani seluruh pesanan dan dalam pengadaan ikan Tenggiri juga terdapat 4 jenis Tenggiri yang dipasarkan oleh Bangliao Hasan yaitu jenis ikan Tenggiri A, B,C, D.

\section{Perspektif Pembelajaran dan Pertumbuhan}

Dalam penelitian ini yang menjadi faktor perspektif pembelajaran dan pertumbuhan adalah tingkat produktivitas karyawan Bangliao Hasan dengan menunjukkan tingkat produktivitas dari unit atau kegiatan yang dinilai dari kepuasan kerja, kesempatan pengembangan karir dan komitmen karyawan.

Berdasarkan data yang diperoleh dari Bangliao Hasan maka peneliti dapat menghitung tingkat produktivitas karyawan seperti pada grafik berikut ini 


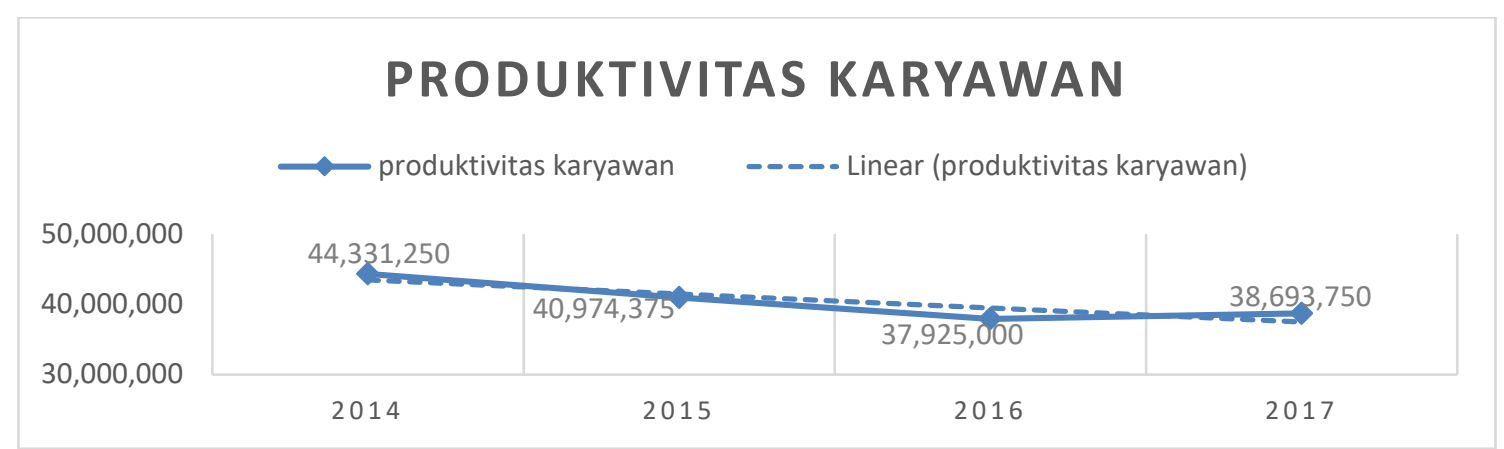

Grafik 4. Produktivitas Karyawan Rantai Pasok Ikan Tenggiri di Bangliao Hasan mempertahankan usahanya atas dasar kegiatan sosial dan ekonominya.

Grafik 4 menunjukkan bahwa hasil uji produktivitas karyawan yang dilakukan pada Bangliao Hasan periode 2014 sampai 2016 memiliki trendline yang menurun dan pada periode 2017 mulai meningkat sebesar Rp.38.693.750. Hal ini berarti, rasio tersebut menunjukkan bahwa dalam perspektif pembelajaran dan pertumbuhan menunjukkan tingkat produktivitas karyawan menurun dan dapat dikatakan belum bertumbuh dengan baik. Hal ini disebabkan penjualan yang terus menurun selama periode 2014 sampai periode 2017, sementara selama periode tersebut Bangliao akan membayar karyawan dengan jumlah karyawan yang sama setiap periode.

\section{KESIMPULAN DAN SARAN}

\section{Kesimpulan}

Berdasarkan penelitian yang telah dilakukan, maka dapat disimpulkan bahwa dengan menggunakan metode Balance Score card maka tingkat kinerja Bangliao Hasan dapat dilihat dari empat tolak ukur yang dimiliki yaitu perspektif keuangan, perspektif proses bisnis internal, perspektif pelanggan, serta perspektif pembelajaran dan pertumbuhan Bangliao Hasan dinyatakan eksistensi. Hal ini berarti Bangliao Hasan mampu

\section{Saran}

Saran yang diberikan kepada Bangliao Hasan untuk memperbaiki kinerja perusahaan dalam meningkatkan rasio aktivitas, rasio peningkatan penjualan, rasio profitabilitas serta meningkatkan produktivitas karyawan agar Bangliao Hasan mempunyai prospek yang baik di masa yang akan datang.

\section{DAFTAR PUSTAKA}

Andryani, Ni Putu Devi. 2013. Pengaruh Pertumbuhan Penjualan, Ukuran Perusahaan, dan Tangibility Asset Terhadap Struktur Modal pada Perusahaan Asuransi yang Terdaftar di Bursa Efek Indonesia. Skripsi.Sarjana Jurusan Manajemen Fakultas Ekonomi dan Bisnis Universitas Udayana Bali.

Assuri, S. 2012. Manajemen Produksi dan Operasi. Lembaga Penerbit FEUL. Jakarta.

Kaplan, R, S., \& David, P. N. (1996). The Balanced Scorecard. Jakarta: Erlangga. 
(2000). Balanced Scorecard: Menerapakan Strategi Menjadi Aksi. Jakarta: Erlangga.

Kamsir.(2012). Analisis Laporan Keuangan.Jakarta : PT. Raja Grafindo Persada.

Kennedy, Nur Azlina dan Anisa Ratna Suzana. 2013. Faktor-Faktor yang Mempengaruhi Struktur Modal pada Perusahaan Real Estate and Property Go Public di Bursa Efek Indonesia. Jurnal Akuntasi, h:1-10.

Lewis, M (2009). The Influence Of Loyalty Programs And ShortTerm Promotion On Customer Retension. Journal Of Marketing Research 281 Vol. XLI.
Rahmasari, L. 2011. Pengaruh Supply Chain Manajemen Terhadap Kinerja Perusahan dan Keunggulan Bersaing : Studi Kasus pada Industri Kreatif Di Provinsi Jawa Tengah. Majalah Ilmiah Informatika Vol. 2 No. 3, September 2011. Universitas AKI.

Riyanto, Bambang. 2011. Dasar-dasar Pembelanjaan Perusahaan. Edisi ke 4. Yogyakarta: Yayasan Penerbit Gajah Mada.

Verni. K., Gesti. M. 2017. Analisis Kinerja Perusahaan Menggunakan Metode Balanced Scorecard (Studi Kasus Pada PT. Aditya Sentana Agro). Jurnal AGORA Vol. 5, No. 1 (2017). 